\title{
Türlerin yok oluşunun antropojenik nedenleri
}

\section{Duygu Tan Gülcan ${ }^{1 *}$ (อ)}

'Dr. | Bağımsız araştırmacı, Türkiye
* Sorumlu Yazar / Corresponding Author Duygu Tan Gülcan Bağımsız araştırmacı E-posta: duygu.tan.mail@gmail.com

Alındı/Received: 25 Haziran / June 2020 Düzeltildi/Revised: 2 Nisan / April 2021

Kabul/Accepted: 2 Nisan / April 2021 Yayımlandı/Published: 28 Haziran / June 2021

\section{Öz}

Günümüzde sıklaşan küresel felaketler, ekolojik sorunların git gide ağırlık kazanacağına ve yaşamları doğrudan etkileyeceğine yönelik bilim insanlarından gelmekte olan uyarlların ciddiyetini ortaya koymaktadır Toplumsal yaşam biçimlerini sarsan felaketler, genel kanının aksine ne şaşırtıcıdır ne de beklenmedik. İnsan eylemlerinin küresel dengeyi alt üst etmekte olduğu ve bu dönüşümün bu ve benzeri sonuçlara gebe olduğu çoktandır dile getirilmektedir. Ekolojik dengelerin hassaslaşması ve krizlere açık hale gelmesinin altında yatan nedenleri anlayabilmek, insan eylemleri sonucu yerküreye verilen zararı tekrar gözden geçirmeyi gerektirir. Ancak bu şekilde verilen hasar azaltılarak yerküreyle daha uyumlu bir yaşam biçimi geliștirmek mümkün olacaktır. Bu anlamda yeryüzünde yaşayan insan dışındaki canlılar üzerinde binlerce yıldır yaratılmış ve artarak devam eden baskının incelenmesi, ekolojik dengenin nasıl zarar gördügünü anlamak açısından önemli görülmektedir. Yukarıda değinilen amaç doğrultusunda bu çalışmada türlerin yok oluşunun doğal nedenleri ile insana bağli/antropojenik nedenleri incelenmekte, bu iki etken arasındaki farklar değerlendirilmektedir. Çalışmada, antropojenik yok oluşların doğal süreçte kendiliğinden ortaya çıkan ve kaybolan yok oluşlardan pek çok açıdan farklılık gösterdiği ve küresel denge açısından ciddiye alınması gereken bir fenomen olduğu savunulmaktadır.

Anahtar sözcükler: Kitlesel yok oluş, antropojenik yok oluş, evrimsel ekoloji, ekolojik denge

\section{Giriş}

Türlerin yok oluşu, bir türün çevresel koșullara uyum sağlayabilmek için yeni bir donanım kazanması yoluyla gerçekleșebildiği gibi daha büyük ve yıkıcı çevresel değişimler sonucu yeni bir donanım kazanamadan tamamen tükenmesi şeklinde de gerçekleşebilir. İkinci durumda soyu devam ettirecek hiçbir birey hayatta kalamaz ve soy ağac1 son bulur. Yaşam tarihi boyunca, yeryüzünde yaşayan türlerin önemli bir bölümünün yok olduğu kitlesel yok oluşlar yaşanmıştır. Kitlesel yok oluş ne kadar y1kıcı ve geniş çaplı olsa da bir süre sonra biyosfer kendini iyileștirmeyi bașarmıș, biyoçeșitlilik tekrar ortaya çıkmıştır. Bu sebeple kitlesel yok oluşların ve yeniden uyanışların oluşturduğu döngüsel süreç, yaşamın doğal bir parçası olarak görülmektedir. Öte

\section{The anthropogenic causes of extinction \\ Abstract}

Global disasters, which are becoming more frequent today, reveal the seriousness of the warnings from scientists that ecological problems will gradually become more prominent and will directly affect lives. Contrary to popular belief, the disasters that have shaken social lifestyles are neither surprising nor unexpected. In fact, buman activities has long been upsetting the global equilibrium and this transition is about to end up with these and similar consequences. To perceive the reasons lying beneath the ecological balance that become delicate and fragile, it's essential to re-examine the global damage caused by buman activities. Only thus it will be possible to reduce the damage given to the earth and to develop a more nature- friendly, consistent living-style. Thus studying the thousands years of suppression imposed on the living forms other than bumans seems important to understand how the ecological balance has been damaged. To this end, in this study natural and buman based/anthropogenic causes of extinction were handled and the differences between these two factors were evaluated. The study argues that the anthropogenic extinction, in various ways, differ than those of naturally occurred and terminated extinctions and thus must be taken into account as a serious phenomenon in order to achieve global ecological balance.

Key words: Mass extinction, anthropogenic extinction, evolutionary ecology, ecological balance

yandan, Homo sapiens'in yaşam sahnesine çıkmasılya birlikte türlerin yok oluşlarında yeni bir etkenin varlığından söz etmek mümkündür. İnsan eylemleri, karmaşık süreçler içinde ve doğal döngüden farklı yollarla, türlerin yok oluşuna sebep olabilmektedir. Bu çalışma, antropojenik etkilerin biyosferde yaşanan yok oluş-uyanış döngüsünde sıradan bir etmen değil, aksine dönüşü olmayan zararlara neden olan, doğal döngünün dişında ve ondan farklı bir etmen olduğunu savunmaktadir.

\section{Türlerin tükenişi}

Türlerin tükenişi, fosil kayıtlanından yola çıkılarak incelendiğinde, hem devamlılığı hem de yok oluşu ifade eden geniş bir kavramdır. Kendisinden başka bir türün 
evrilmesiyle yok olan bir tür için, her ne kadar nesli başka türlerle devam ediyor olsa da, tükenmiş terimi kullanılır. Bu şekilde evrim yoluyla tükeniş, türlerin uyum sağlayarak yaşamlarına devam etmelerini, gelişmiş bir formun daha ilkel olanın yerini almasinı ifade eder. Öte yandan, kendilerinden yeni türlerin evrilmediği durumlarda soyları tükenen ve daha başarılı olanlar tarafindan yerleri doldurulan türler için de tükenme/ yok olma terimi kullanılır. İkinci sinıfta incelenen tükeniş ilkinin aksine hızlıdır, geniş kapsamlıdır ve türlerin yeni koşullara adapte olamayacakları kadar büyük bir felakettir. Türlerde soy sona erer ve tür yeni koşullara uyum sağlayabilen bireyler tarafından devam ettirilemez. Bu çalışmada tükeniş/yok oluş, soyların yeni türler tarafindan devam ettirilmeden tamamen tükendiği durumları tanımlamak için kullanılacaktır (Aitken, 1998, s. 394; Schuster ve Schüle, 2000, s. 223).

Türlerin yok oluşu, tarih boyunca birçok defa karşılaşılan bir olgudur. Türler, karşılaştıkları çevresel değişim sonucu yeni donanım geliştirerek yeni koşullara adapte olamadikları durumlarda yok olurlar. Ancak, karşılaşılan çevresel değişimler, kimi durumlarda birkaç türün yok oluşundan çok daha geniş bir etkiye sebep olur. Böyle durumlarda, kitlesel yok oluş (mass extinction) olarak tanımlanan, geniş kapsamlı tükenişler yaşanır. 19. yüzyıldan itibaren yapılan çalışmalarda, gezegenin tarihinde beş büyük kitlesel yok oluşun gerçekleştiği düşünülmektedir. Büyük yok oluşların iklim değişikliği, büyük ölçekli volkanik etkinlikler, deniz düzeyindeki değişimler ve meteor çarpması sonucu ortaya çıktığına dair çeşitli hipotezler ileri sürülmektedir (Brannen, 2017, s. 8; Jones, 2014, s. 377; Palmer ve Barrett, 2010, s. 183 Hallam, 2005, s. 21). Öte yandan Homo sapiens, ilk ortaya çıktı̆̆1 zamanlardan bu yana, türlerin tükenişinde önemli bir faktör olagelmiştir. Ancak, özellikle sanayi devrimi sonrasında bu etki muazzam boyutlarda artmıştır. Sürekli büyümeye dayalı bir ekonominin küresel boyutlarda benimsenmesi, doğal kaynakların ihtiyaca değil ekonomiye koşut bir biçimde kullanılmasını doğurmuştur. Bir yandan nüfus artışı ve kentleşme, diğer yandan artan üretim ve tüketim ihtiyacina cevap verebilmek için kullanılan doğal kaynaklar, insan dişı türlerin yaşam koşullarını giderek zayıflatmıştır. Nihayet bu etkiler 6. yok oluş olarak ifade edilen ve geçmiş beş büyük yok oluşla kıyaslanır büyüklükte bir yıkım süreci halini almıştır (Pievani, 2014, s. 89-90). Araştırmacılar, Üst Paleolitik ve Neolitik Çăg insanının tarih sahnesine çıkmasıyla birlikte başlayan dönemde yaşanan tür kayıplarının, önceki dönemin bin ila on bin katı olduğu konusunda görüş birliğindedir. Farklı yöntemler kullanılarak elde edilen bulgulara göre, Paleolitik öncesi dönemde yok olan türlerin ortalaması, yılda milyonda bir tür olarak bulunmuştur. Diğer taraftan Paleolitik sonrası dönemde yani son 12 bin y1lda ortalama y1lda 1 ila 10 bin türün yok olduğu düşünülmektedir (Wilson, 2003, s. 99-100). Bugün gelinen noktada Birleşmiş Milletler Dünya Koruma İzleme Merkezi (UN WCMC) verilerine göre 1 milyon tür yok olma tehlikesi altındadır ve bu gidişat değiştirilemezse yakın gelecekte yaşam döngüsü üzerinde büyük sorunlar ortaya çıkacaktır (WCMC, 2021).

\section{Doğal yok oluşa karşın antropojenik yok oluş}

Antropojenik yok oluş ile doğal yok oluş arasında bir ayırıma gitmeden önce, böyle bir ayırımın gerekli olup olmadiğ1 sorgulanabilir. Türlerin yok oluşunun doğal nedenlerden mi yoksa antropojenik nedenlerden mi kaynaklandı̆̆ı önemli midir? Aitken'e (1998) göre yok oluşa neden olan doğal nedenler ile antropojenik nedenler yapısal olarak birbirlerinden oldukça farklıdır ve doğurdukları sonuçlar bakımından da birbirlerinden net biçimde ayrilırlar.

$\mathrm{Bu}$ görüşe göre doğal ile antopojenik etkenler arasında dört temel fark vardır. İlk olarak Antropojenik yok oluşun merkezindeki insan, doğal nedenlerin aksine doğal seleksiyon ile evrilen organik bir faktördür ve sistemin bir parçasıdır. Bu anlamda insanlar, yavaş yavaş nişlere yayılan, habitatları sömüren, diğer türleri bulundukları habitatlardan dişlayan ve zamanla tüm yaşam alanlarına egemen olan bir türdür. Bu özellikleriyle, yaşam alanlarını parçalayan, harap eden fakat sonra kaybolan harici faktörlerden oldukça farklıdır. Doğal yok oluş bir yaralanmaya benzetilebilirken, antropojenik yok oluş daha çok bağ1şılklık sisteminin çöküşüne neden olan bir hastalığa benzetilebilir (Aitken, 1998, s. 398).

İkinci büyük fark, kitlesel yok oluşlara neden olan faktörlerin kalıcılığına ilişkindir. Doğal nedenlerle oluşan kitle yok oluşları kısıtlı bir dönem için geçerlidir. Yok oluşun gerçekleşmesine neden olan faktörler ortaya çıktı̆̆ında biyota harap olur, ancak sonrasında büyük felaket ortadan kalkar ve biyota kendisini onarır (Brannen, 2017, s. 8, Alroy, 2008, s. 11536). Öte yandan, antropojenik faktörler artan bir süreklilik gösterir. Yok oluşa neden olan faktörlere maruz kalan biyota genellikle kendini onaramaz, çünkü faktörler ortadan kalkmaz, kalıcılık gösterir. Kalıcılık özelliğiyle antropojenik faktörler, önceki kitlesel yok oluşlara kıyasla biyotaya çok daha büyük ve kalıcı zarar vermektedir (Aitken, 1998, s. 398-399).

Aitken'in ileri sürdüğü bir diğer fark, yok oluşa neden olan doğal faktörlerin kurallara bağlı, oysa antropojenik faktörlerin rastlantısal olmasıdır. Bazı türlerin geçmiş yok oluşlardan sağ çıkmalarının nedeni bir takım özel beceriler ve donanımlar geliştirmeleridir. Örneğin memelilerin Kretase döneminde yaşanan buzul çağından sağ kurtulmalarının nedeni, küçük boyutlarıdır. Antropojenik kökenli yok oluşlarda da süreç aynı şekilde çalışıyor gibi görünür. Örneğin yaşam alanlarının 
parçalanması sonucu hayatta kalan türler, bu faktöre küçük yaşam alanlarına uyum gösterebilme, gelişmiş yayılma becerisi, hızlı üreyebilme gibi donanımlar geliştirerek en iyi uyum sağlayanlardır. Ancak, geçmişte yaşanan yok oluşlara bakıldı̆̆ında, yok oluşa neden olan faktörlerin sabit kurallarla sınırlı olduğu görülür. Öte yandan, antropojenik faktörler büyük bir çeşitlilik içerisinde ve karmaşıktır, öyle ki bu faktörleri herhangi bir kurala bağlamak imkânsızdır. Eğer bir tür, küçük beden boyutu gibi özel bir donanıma sahip olduğu için antropojenik yok oluştan kurtulmuşsa, ona yakın türlerin de benzer şekilde kurtulması beklenir. Oysa antropojenik yok oluşun kuralları tamamen insanların tercih, amaç ve isteklerine göre belirlendiği için, hayatta kalmaya yarayan donanımlar veya özelliklerle ilgili genellemeler yapmak mümkün değildir. Antropojenik yok oluş kuralsızdır, rastlantısaldır ve genellenemez. Hangi türün yaşamaya devam edeceği ya da hangi türün yok olacağı insanların canlılara atfettiği biyolojik önem, estetik anlayış, popüler talepler, ekonomik kayg1 ve antropojenik ihtiyaçlar gibi birçok değişken tarafından rastlantısal olarak belirlenir (Aitken, 1998, s. 400-402).

Son olarak, doğal ve antropojenik faktörler, yarattıkları etkiye göre de farklılaşırlar. Geçmişte yaşanan kitle yok oluşlarının her birinin sonunda, kaybedilen türlerin sayısı ne kadar fazla da olsa, biyolojik çeşitlilik geri kazanılmıştır. Geri kazanım süreci uzun sürmüş, örneğin Permiyen döneminin sonunda yaşanan kitle yok oluşundan sonra biyoçeşitliliğin tekrar oluşabilmesi 50 milyon yil sürmüştür, fakat yine de doğal süreç içinde gerçekleşen yok oluşlardan sonra, biyoçeşitlilik yeniden oluşmuştur. Öte yandan, bilim insanları bugün yaşanmakta olan antropojenik kitlesel yok oluşun öncekilere oranla çok daha büyük bir tahribat yarattığını tahmin etmektedir. Biyosferin kendini onarmas1 ve biyoçeşitliliğin tekrar sağlanması için öncekilere oranla çok daha uzun bir zamana ihtiyaç duyulacağ1 tahmin edilmektedir. Dahası, yok oluşa neden olan insan davranışlarının, onarım sürecinin çalışmasına engel olduğu, bu sebeple çeşitliliğin canlanamadiğ düşünülmektedir. Kaybolanlar yerine tamamen yeni organizmaların evrilmesi olası görülmemektedir (Aitken, 1998, s. 405; Broswimmer, 2002, s. 3).

\section{Antropojenik yok oluş nedenleri}

Jha (2010, s. 1-3), doğal felaketlerin depremler, volkanik faaliyetler veya toprak kayması gibi jeofirik, firtına, tufan, aşırı sıcaklık veya söndürülemeyen yangınlar gibi hava-yoğusumsal ve epidemi veya böcek enfeksiyonlar1 gibi biyolojik olmak üzere üç başlikta incelenebileceğini dile getirir. Bununla beraber antropojenik felaketleri teknolojik ve sosyolojik olmak üzere iki başlikta incelemenin mümkün olduğuna değinir. Bununla birlikte Jha’nın (2010) da kabul ettiği gibi günümüzde, doğal felaketler başlığı altında incelenen maddelerin de antropojenik nedenlere bağlı olduğu yaygın biçimde kabul görmektedir. Dahası, antropojenik etki o kadar derindir ki, Crutzen ve Stoermer (2000, s. 17-18) içinde bulunduğumuz çağ1 Antroposen olarak isimlendirmeyi önermiştir. İnsanlığın tek bir özne olarak küresel bir dönüşümden sorumlu tutulmasına yönelik itirazlar bir tarafa birakilirsa (Malm ve Hornborg, 2014, s. 2-3), böylesi bir terminolojinin bilim dünyasında geniş yankı bulduğunu ve yaygın kabul gördüğünü belirtmek gerekir.

\section{Iklim değişimi}

Atmosferdeki $\mathrm{CO}_{2}$ seviyesinin artışına bağlı olarak gerçekleşen iklim değişikliği, hem atmosferik dengeyi hem de yeryüzündeki yaşamsal döngülerin işleyişini tehdit eder boyutlara ulaşmıştır. Yapılan bir araştırma, 1980 y1lından bu yana iklim kaynaklı felaketlerin \%40 oranında arttığını göstermektedir (Renner, 2014, s. 483). Bu durum genellikle vurgulandığ1 gibi yalnızca türümüzün karşılaşacağı ekonomik, demografik ve sosyal krizlere yol açmakla kalmayıp, bütünsel olarak gezegeni tehdit etmektedir (Lovejoy ve Hannah, 2019, s. 3).

İklim değişiminin türlerin yaşamına ne gibi etkilerde bulunacağ1, türlerin yeni iklim koşullarına uyum sağlayıp sağlayamayacağı, yeni yaşam alanlarına göç edip etmeyecekleri veya yok oluşla karşılaşıp karşılaşmayacakları on yıllardır incelenmektedir. Türlerin iklim değişiminden nasıl etkileneceklerini öngörebilmek için yapılan bir çalışmada antropojenik iklim değişiminin önceki iklim değişimlerine göre çok daha yıkıcı olacağı öngörülmektedir. Bunun nedeni ise yaşam alanı kayıpları olarak belirtilmektedir. İklim değişimleri sonucu türlerin yaşamaları için daha uygun çevresel koşullar barındıran bölgelere göçmekte oldukları gözlenmekte ve yakın zamanda bu göçlerin devam edeceği tahmin edilmektedir. Ancak geçmiş iklim değişimlerinin aksine, bugün yaşam alanlarında büyük kayıplar meydana gelmiştir. Daha açık bir ifadeyle göç edilebilir uygun yaşam alanları artık çok daha sınırlıdır ve mevcut yaşam alanları göç edecek tüm türler için yeterli olmayacaktır. Yayılma yeteneği yüksek olan türlerin iklim değişikliğini daha iyi tolere edecekleri düşünülmektedir. Buna karşın yayılma yetileri ve yaşam alanına hâkim olma yeteneği düşük olan türlerin antropojenik iklim değişikliğinde yok olacakları tahmin edilmektedir (Travis, 2003, s. 467472).

İklim krizine bağlı gerçekleşebilecek biyolojik kayıplar değerlendirildiğinde krizin çok boyutluluğu ortaya çıkmaktadır. Habitat kayıpları veya orman kayıpları gibi değişkenler temel alınarak yapılan pek çok analiz genellikle birbiriyle tutarlı ve oldukça yüksek risk oranları ortaya koymaktadır. Öyle ki bu çalışmalardan bazılarında yok oluşla yüzleşecek türlerin \%30-40'ları 
bulduğu görülmektedir (Lovejoy ve Hannah, 2019, s. 3). Chris Thomas liderliğinde yapılan bir analizde ise \%18-34 değerinde bir yok oluş öngörülmektedir. Bu say1, 5 milyon karasal türe uygulandığında, 900,000 ile 1,7 milyon arasında bir değeri ifade eder (Thomas vd., 2004). Dahası küresel iklim değişiminin ortalama bir milyon yaşamı tehdit ettiği vurgulanırken, bu sayının yalnızca karasal türleri kapsadığının altını çizilmektedir (Hannah, 2012, s. 3-5). Oysa küresel 1sınma, okyanus suyu sicaklıklarını artıracak ve bu sicaklık bitkisel planktonların önemli oranda azalmasıyla sonuçlanacaktır. Sucul ekosistemlerdeki birincil üretici olan bitkisel planktonların azalması tüm deniz yaşamının ciddi bir tehlikeyle karşılaşacağı anlamına gelmektedir. (Foster ve Magdoff, 2014, s. 14-16). Dolayisiyla 1 milyon tür, sucul türleri dişarıda bıraktığı için oldukça iyimser bir tablo ortaya koymaktadır.

\section{Türlerin taşınması}

Antropojenik yollarla türlerin taşınması, tek başına bölgesel yok oluşların ortaya çıkması için yeterli bir etmendir. Bir türü dışarıdan, endemik türlerin bulunduğu izole bir ortama taşımak, o bölgedeki flora ve faunanın milyonlarca yll boyunca uyum gösterdikleri çevresel ortamı bir anda değiştirebilmektedir (Gaston, 2005, s. 243).

Geçmişte türlerin taşınması, deniz seviyesinde oluşan değişiklikler veya tektonik plakaların hareketleri sonucu kara köprülerinin oluşmasiyla doğal süreç içinde de orta çıkmıştır. Örneğin Pliyosen'de Panama Kanalı'nın oluşması sonucu Kuzey Amerika'dan güneye göç eden türler güneydeki birçok türün yok olmasına neden olmuştur. Öte yandan, doğa olayları sonucunda türlerin taşınması, antropojenik nedenlerle gerçekleşen taşınmalara göre çok daha sınırlı bir etki yaratmıştır. Bunun nedeni ise ilk durumda çok fazla türün yer değiştirmemesi ve bu durumdan sınırlı sayıda türün etkilenmesi olarak düşünülmektedir. Öte yandan antropojenik nedenlerle türlerin taşınması çok daha geniş bir etki yaratmış ve büyük sayıda endemik türün yok olmasına neden olmuştur. Örneğin milyonlarca yıl dış dünyadan izole bir yaşam süren okyanus adalarındaki endemik türler için, insanlar tarafından taşınan yırtıcı türlerle karşılaşmak ölümcül olmuştur (Schuster ve Schüle, 2000, s. 223-224).

İnsana bağlı nedenlerle türlerin yok oluşunun en can alıcı örnekleri sömürgecilik döneminde yaşanmıştır (Ponting, 2000, s. 145-149). Bununla beraber türlerin taşınması halen tür yok oluşlarında önemli bir faktör olmaya devam etmektedir. Örneğin 1990'larda Afrika'nın Viktorya Gölü'nde yaşanan felaketin temel nedeni tür taşınmasıdır. Bölgedeki balıkçılı̆̆ın geliştirilmesi amacıyla dışarıdan ekosisteme taşınan Nil Levreği, on y1llar içinde adeta bir "Hiroşima" etkisine neden olarak 200'den fazla kuş türünün yok oluşuna neden olmuştur (Leakey ve Lewin, 1994, s. 234).

\section{Avcılık}

Yaklaşık 10.000 yıl önce megafaunanın olağandışı yok oluşunun, insanların aşırı avlanması sonucu meydana geldiğine yönelik hipotezler geliştirilmiştir. Mamut, bizon, deve, mastodon gibi iri ve hantal megaotçulların, avlanmaları kolay ve g1da değerlerinin yüksek olmas1, insanlar tarafindan aşırı miktarda avlanmalarının bir nedeni olarak düşünülmektedir. Geniş ve iri hayvanlarda düşük büyüme hızı, düşük doğurganlık, uzun yaşam ve uzun ergenlik dönemlerinin biyolojik karakteristik olduğu bilinmektedir. Karakteristik özellikleri nedeniyle megaotçullar aşırı avlanmayı tolere edemezler. $\mathrm{Bu}$ dönemde avlanma hızının, megaotçul türlerin biyolojik büyüme hızından yüksek düşünülmektedir (Smith, 1975, s. 728).

Megafaunanın yok oluşu, avcilık yoluyla tür yok oluşlarının başlangıcını oluşturur. Ancak avcilığın boyutlar1, avc1-toplayic1 toplumların yerini tarım toplumunun almasıyla genişlemiştir. Avc1-toplayıc1 toplumlar için avcllık ve av miktarı, tüketim ihtiyaçları tarafindan belirlenir. Oysa tarım toplumu ile birlikte yerleşik düzene geçilmesi, yapay ekosistemlerin oluşturulmasını zorunlu kılmıştır. Bunun yanı sıra, yerleşik yaşamla birlikte sağlanan nüfus artışı, doğal kaynaklara olan ihtiyac1 da son derece hizlı şekilde arttırmıştır. Zamanla ticaretin gelişmesi ile toplumların tüketim için değil, değişim amacıyla avlanmalarının önünü açmıştır. Örneğin erken kürk avcıllğ̆ Orta Çă̆ başlarında, Avrupalı asillerin zevklerine hitap etmek amaciyla yayginlaşmıs, sincap, sansar, gelincik, samur ve tilki gibi hayvanlar kürkleri için neredeyse tükenene kadar avlanmıştır (Broswimmer, 2002, s. 62-63)

Tarımsal yaşama "zararlı" kabul edilen türlerin avlanmas1/yok edilmesi ahlaki kabul görmüş ve yüzyıllar boyunca siyasi kurumlarca da desteklenmiştir. Örneğin 16. yüzyıl İngiltere'sinde tilki, sıçan, fare, doğan, şahin gibi hayvanların avlanması ödüller ile teşvik edilmiştir. Diğer taraftan avcilığın bir spor olarak algilanması, başlangıçta bu anlayışın ortaya çıktı̆̆1 Avrupa'da ve sömürgecilikle birlikte hızla yaygınlaşarak etkisini küresel ölçekte göstermiştir. Çeşitli kuş türleri başta olmak üzere balina, fok, kanguru gibi pek çok yaban hayvanının neslinin tükenmesiyle sonuçlanmıştır (Ponting, 2000, s. 144-146). Spor amaçlı avcılık zamanla azalmakta olsa da bugün hala önemli bir sorun teşkil etmektedir. Geyik, su kuşları, yayla kuşları, çakallar, kirpiler ve kargalar en s1k avlanan türler olarak bilinmektedir. Bununla birlikte, nesli tükenmekte olan pek çok yaban türü için önemli bir tehdit teşkil etmektedir. Örneğin Hazar Kaplanı'nın (Panthera tigris virgata) son üyesinin 1970'te Türkiye'de vurulduğu düşünülmektedir (Glavin, 2014, s. 26). 
Diğer taraftan sanayileşmeyle birlikte avcılık, tarım toplumlarının ulaşamayacağı boyutlara ulaşmıştır. Örneğin tarım toplumlarında balık avcıllğı, yalnızca kıyı bölgelerinin faydalandığ1 bir geçim biçimiyken, sanayileşmeyle birlikte gelişen teknoloji, balık avcilığının sınırlılıklarını yok etmiştir. 19. yüzyılla birlikte okyanusta başlayan balık avcılı̆̆ı, balığın ucuz bir gida olarak tüketilebilmesinin önünü açmıştır. Böylece balı̆̆a karş1 ortaya çıkan muazzam boyutlardaki talep, balık avcillğının, rezervler kuruyana kadar devam etmesine neden olmuştur (Hilborn ve Hilborn, 2012, s. 12-17). Bugün Birleşmiş Milletler Tarım ve Gıda Örgütü (FAO) balık yataklarının sürdürülebilir kullanımı için ilkeler belirlemekte, sürdürülebilirlik seviyesinin altına düşen yatakların koruma statüsü ile korunması gerektiğini dile getirmektedir (FAO, 2021).

\section{Yaşam alanlarının azalması}

Her ne kadar avcillk gibi yollarla türlerin doğrudan hedef alınması önemli bir faktör olsa da yok oluşa neden olan temel nedenin yaşam alanlarının kaybı olduğu düşünülmektedir (Leakey ve Lewin, 1994, s. 234; Aitken, 1998, s. 401). İnsan nüfusunun büyüklüğü ve yoğunluğu ile orman kaybı, ormanlık alanların parçalanmas1, arazi dönüşümü ve türlerin başka yerlere taşınması arasında olumlu bir korelasyon bulunmaktadır. İnsan yoğunluğundaki artış, doğal yaşam alanlarının parçalanması veya tamamen yok olmasina neden olduğu ve bunun yanında, yayılma, kirlilik ve yeni türlerin taşınması gibi yan sonuçlar doğurduğu için, tür zenginliğinin azalmasina neden olmaktadır (Gaston, 2005, s. 241-242; Michalski ve Peres, 2005, s. 393).

Genetik çeşitlenmenin artan nüfuslarda, azalan veya durağan nüfuslara göre daha fazla ortaya çıtığı bilinmektedir. Yaşam alanlarının sürekli azalması ise, tür popülasyonlarının azalmasına neden olmaktadır. $\mathrm{Bu}$ nedenle, yaşam alanlarının tahribatı sağlıklı evrimsel ilerlemelerin oraya çıkışını engellemektedir. Bugün korunan doğal alanların bile artmak yerine azalmakta olmas1 veya yollar, köprüler veya yerleşkeler uğruna tamamen gözden çıkarılması, genetik çeşitliliği ve evrimsel ilerlemeyi imkânsız kılmaktadır (Mammadov, 2011, s. 9; Aitken, 1998, s. 405-406).

Genellikle geniş alanlarda yaşayan birçok tür, insanlar tarafından belirlenen çok daha küçük alanlarda yaşamak durumunda bırakılmaktadır. Böylece yaşam alanlarının kaybı birçok türün yok oluşuyla sonuçlanır (Pimm ve Raven, 2000, s. 843). Örneğin 20. yüzyllın başlarında 100.000 olan kaplan popülasyonu yüzyılın sonuna gelindiğinde 7.000 'lere düşmüştür. Hayatta kalan kaplanların büyük bölümü ise korunan alanlarda, milli parklarda veya hayvanat bahçelerinde yaşamaktadır (Glavin, 2014, s. 26). Ormanin adamı anlamına gelen Orangutan, ağaçlık alanlarda yaşayan dolayisıyla ormansızlaşmaya karşı en savunmasız türlerden biridir. World Wildlife Fund'ın (WWF) verilerine göre yüzyll önce 230,000 olan nüfusları bugün 100,000'ler dolaylarına düşmüş, Sumatra Orangutanı ile Tapanuli Orangutanı ise tehdit altındaki türler arasında yer almaktadır (WWF, 2021). Nüfus ve doğal kaynak tüketim artışına bağlı olarak, yeryüzündeki türlerin yaklaşık yarısına ev sahipliği yapan tropik yağmur ormanlarının tahrip edilmesi, türlerin yok oluşundaki en önemli halkayı oluşturmaktadır (Leakey ve Lewin, 1994, s. 234).

Yaşam alanının yok oluşu ile türlerin yok oluşu arasındaki ilişki üzerine yapılan bir araştırma önemli sonuçlar ortaya koymuştur. Çalışmaya göre, belirli bir eşiğin üzerindeki yaşam alanı yok oluşu, bölgede yaşanan tür yok oluşlarının temel nedeni olarak ortaya çıkmaktadır. Bazı türler, yaşam alanı kaybına diğer türlere göre daha duyarlıdır. Bu duyarlı türler izlenerek, bölgesel olarak yaşam alanı kayıplarının kritik düzeyleri belirlenebilir. Örneğin kuzeyli benekli baykuş (Strix occidentalis), yaşam alanı kaybına yüksek duyarlılıkta olduğu için, yaşadığı bölgedeki kritik yaşam alanı düzeyini göstermektedir. Baykuşun yok olması, yaşam alanı kaybının kritik düzeyde olduğunu gösterecek, bu durum yok oluş sırasının diğer türlere geldiği anlamını taşıyacaktır. Türler, nesillerini devam ettirme kapasitesine sahip olsalar dahi, yaşam alanı kayıpları sonucu yok oluştan kurtulamayacaklardır (Lande, 1987). Farklı türler üzerinden geliştirilen modeller, bir yandan güncel tür yayılımlarının niceliksel olarak ortaya konmasını sağlamakta, diğer yandan yaşam alanı kayıpları sonucu gerçekleşecek olası göç veya yok oluşların tahmin edilmesine katkı sunmaktadır (Travis, 2003, s. 467). Bu gibi çalışmalar, yaşam alanı kaybı ile yok oluş arasındaki ilişkiyi somut bir şekilde ortaya koymaları açısından yararlı oldukları kadar, türlerin korunmasına ilişkin çalışmalara da önemli katkılar sağlamaktadır.

\section{Nüfus artışı}

Doğal çevreyi etkileyen antropojenik nedenlere bakıldığında biyoçeşitliliği ve ekosistemi tehdit eden önemli faktörlerden bir diğerinin insan nüfusunun hızlı artış1 ve yüksek yoğunluğu olduğu görülür. İnsan, küçük gruplar halinde bile çevresindeki ekosistemi etkileyip zarar verebilecek güçtedir. Buna en güzel örnek yukarıda bahsedilen megaotçulların yok oluşu olabilir. Diğer taraftan, insan nüfusunun ve yoğunluğunun artış1, ekolojik sistemler ve dolayısıyla biyoçeşitlilik üzerinde ilave baskı yaratmaktadır. Kentleşme ve nüfus artışına bağlı olarak kentlerin genişlemesi, artan nüfusun ihtiyaçlarına cevap verecek alt yapı ihtiyacını doğurur. Bir yandan yeni yollar, barajlar ve konutlar yapilırken, diğer taraftan ihtiyaç duyulan doğal kaynaklar ve yerleşim için doğal yaşam alanları yok edilir. Nüfus artışına bağlı olarak gida üretimi dolayısıyla tarım alanlarının artması kaçınılmazdır. Gübre kullanımının artmasından tatlı su sistemlerinin kirlenmesine kadar pek çok sorunun katlanarak artması da aynı şekilde gerçekleşir (Ponting, 
2000, s. 214). Dolayısıyla nüfus artışı ister istemez yaşam alanlarının azalmasını, ormansızlaşmayı ve kirlilĭği beraberinde getirir (McKee, 2003, s. 139-140, Gaston, 2005 , s. 239). İnsan nüfusunun artış1 ve yay1lımı, diğer türlerin yaşam alanlarından uzaklaştırılmalarına ve nihayetinde yok olmalarına neden olmaktadır. Bunun yanında, nüfus artsssıla birlikte, kaynak tüketimi de artmaktadır. Bu da diğer türler için kullanılabilecek olan kaynakların sürekli azalmasına yol açar (McKee vd., 2003, s. 163).

İnsan nüfusunda 2050 yllına kadar 2-4 milyarlık bir artış öngörülmektedir. 1 milyar insana ancak 1800’lerde ulaşılmışken, bugün aynı sayıya ulaşmak için on yıl yeterlidir (Gaston, 2005, s. 243-244). İnsan yoğunluğu ve tehlikedeki türler arasındaki ilişki incelendiğinde, ikisi arasında güçlü bir korelasyon görülmektedir. İnsan nüfusunun artmaya devam etmesi, farklı bölgelerde yaşayan tehlikedeki tür sayısının artacağına işaret eder (McKee vd., 2003, s. 161-162). Diğer yandan 2050 y1lına kadar öngörülen dünya nüfus artışının hemen hemen tamamı Asya, Latin Amerika ve Afrika'daki düşük gelirli toplumlardayaşanacaktır.EkonomikKalkınmaveİşbirliği Örgütü'nün öngörülerine göre, dünya ekonomisinin üçe katlaması beklenmektedir. Kaydedilecek olan ekonomik büyümenin büyük bölümünün düşük gelirli toplumlar tarafindan gerçekleştirileceği düşünülmekte, yoksul ülkelerin ekonomik gelirlerini 5- 6 kat arttıracakları değerlendirilmektedir. $\mathrm{Bu}$ gelişme ile tarihte ilk defa mutlak yoksulluk ortadan kalkacak ve ortasınıf yurttaşlanın sayısı 1,5 milyardan 5-6 milyara yükselecektir (Château vd., 2011). Yoksulluk karşısında kazanılması beklenen bu başarının doğal kaynaklar üzerinde yaratacağ1 bask1 ise muazzam miktarda olacaktır. Şimdiden pek çok ülkenin doğal kaynaklarının en zengin \%20'lik kesimin çıkarına tüketildiği, kalan \%80'in ise pastadan henüz çok küçük bir pay kullandığ1 bilinmektedir. Yakın gelecekte yaşanacak ekonomik kalkınma ile zenginleşen düşük gelirli toplumların da en zengin \%20'nin sahip olduğu yaşam tarzına ulaşma arzusu, doğal kaynaklar üzerindeki baskının muazzam boyutlarda artacağına işaret etmektedir (Rockstörm ve Klum, 2015, s. 37).

\section{Sanayileşme ve Teknoloji}

Her ne kadar avc1 toplayıcı ve tarım toplumları türlerin yok oluşuna neden olmuşlarsa da, antropojenik yok oluş büyük oranda sanayi toplumunun ürünüdür. Sanayi toplumunun ortaya çıkışında Ortaçağ sonlarında Avrupa'da yaşanan felsefi dönüşüm önemli rol oynamıştır. Aydınlanma çağı bir taraftan feodal toplumsal yapının parçalanmasını hazırlarken, diğer taraftan insanı merkeze alan ve doğanın tüm unsurlarının üstünde konumlandıran bir anlayışın benimsenmesine aracı olmuştur. Böylece sanayi toplumunun ihtiyaç duyacağ1 doğanın tahrip edilmesi süreci meşruiyet kazanmıştır. Diğer taraftan insanın aklı ile diğer canlılardan ayrılması ve kendi gönencini arttıracak güce sahip olduğu fikri ile gelişme, büyüme ve kalkınma öncelikli hedefler olarak görülmüş, kabul edilmiştir. Böylece sanayi devrimi sonrasinda kapitalist ekonominin serpilmesinin önündeki duran ahlâkî normlar ortadan kalkmıştır (Ünder, 1996, s. 35- 77; Collingwood: 1999, s. 131-134; Burkett, 2004, s. 103-115; Des Jardins, 2006, s. 63-85; Huberman, 2011, s. 74; Keleş vd., 2012, s. 73-75; Foster, 2012, s. 75-95; Polanyi, 2014, s. 249-265).

Ekonomik büyüme öncelikli gelişme anlayışında teknolojik ilerleme belirleyici olmuştur. Teknoloji, insan hâkimiyetindeki dünyayı büyük ölçüde değiştirmiş, bu değişiklikler, türlerin hayatta kalmak için uyum sağlama çabalarına yeni baskılar yüklemiştir. Örneğin teknolojinin yarattığ1 sanayi kirliliği, biyoçeşitliliği olumsuz yönde etkileyen en önemli faktörlerden biridir. Kimyasal, radyoaktif ve ağır metal kirliliği, ekosistemlere kalıc1 ve çoğunlukla geri dönüşü olmayan zararlar vermektedir. Suların kirlenmesi tatlı su rezervlerini tehdit etmekte ve içme suyu kıtlığına neden olmaktadır (Broswimmer, 2002, s. 118; Barlow, 2009, s. 24-29). Havanın kirlenmesi doğrudan canlıların sağlığını riske atmaktadır. Örneğin 19. ve 20. yüzyılda sanayileşmenin merkezi Londra'da gerçekleşen dumanlı sisin binlerce insanın ölümüne yol açtığ1 bilinmektedir (Ponting, 2000, s. 315). Diğer taraftan tarımsal amaçlı azot ve kükürt kullanımının neden olduğu asit yağmurları, yağış döngüsüyle toprağın asit oranını arttırmaktadır. Asit nem, toprak ve göl yataklarına çökelmiş ağır metallerle tepkimeye girerek, aksi halde ortaya çıkmayacak olan zararlı maddelerin ekolojik döngülere karışmasına yol açmaktadır. Böylece zararlı kimyasallar akarsular ve yeraltı suları ile ekosistemlere dağılır. (Vitousek vd., 1997, s. 739-740). Toprak, su ve havada ortaya çıkan kirlilik, gezegensel döngüler yoluyla birbirine karışır. Doğrudan canlıların yaşamlarını tehdit ettiği gibi (Carson, 1962), yaşam alanlarının tahribi yoluyla da tür yok oluşlarına neden olur.

Bunun yanı sıra, teknoloji karşısında türlerin hayatta kalmakiçin başvurdukları uyum sağlama mekanizmalarını genellikle işe yaramamaktadır. Örneğin, kirpi karşısında motorlu bir arac1 ele alırsak, kirpi gibi bir türün araba gibi bir düşmana karş1 yapabileceği hiçbir şey yoktur. Kirpi için araba adapte olunamayacak bir şeydir, kirpi arabadan kaçamaz ve savunma sistemi olan kendini küre formuna sokmak bir işe yaramaz (Aitken, 1998, s. 404).

Diğer taraftan sanayileşme ile üretim hızının ve pazar büyüklüğünün artması, hayvanlar üzerindeki çeşitli baskıların da önemli ölçüde artmasına neden olmuştur. Sanayi avcıllŏgyla ilgili pek çok kısıtlama bulunsa da, araştırmalar türleri tehdit altında bulunan balıkların hala sanayi balıkçılığı yoluyla avlandığını göstermektedir. 
IUCN Kırmızı Listesi’nde yer alan tehdit altındaki balık türlerinin \%94'ü için avcıllk en önemli tehdit olmaya devam etmektedir (Roberson vd., 2020, s. 2). Kısaca, teknoloji genellikle, flora ve faunanin uyum sağlamakta ve karşısında yeni donanımlar geliştirmekte zorlandığı, bu nedenle evrimsel süreci kesintiye uğratan antropojenik bir faktör olarak görülmektedir (Ceballos ve Ehrlich, 2018, s. 1080).

\section{Biyoçeşitlilik ve insan}

2019 y1linda BM Biyolojik Çeşitlilik ve Ekosistem Hizmetleri Hükümetleraras1 Bilim-Politika Platformu tarafindan ortaya konan veriline göre, 1 milyon hayvan ve bitki türü izleyen 10 ylllarda yok olacaktır ve yaşanmakta olan kayıp, insan faaliyetlerinin doğrudan sonucudur. Türlerin yok oluş hızı, geçmiş 10 milyon yilın ortalamasına oranla onlar ile yüzlerce kat daha hızlı gerçekleşmektedir. Verilere göre karasal, tatlı su, denizel, omurgalı ve bitki türlerinin ortalama $\% 25$ 'i yok olma tehlikesi altındadır. 5.9 milyon karasal tür, hayatta kalmalarına olanak sağlayacak yaşam alanı yokluğuyla yüz yüzedir. Uçamayan karasal memelilerin \%47'si, amfibi türlerin $\% 40 ' 1$, denizel türlerin ve mercan resiflerinin \%33'ü, kuşların \%23'ü yok olma tehdidi altındadır. Önümüzdeki on ylllarda gerçekleşecek iklim değişikliği, yaşam alanlarının yok oluşu, ormansızlaşma, maden ve enerji üretimi, tarımsal üretim ve balıkçılık alanlarındaki olumlu veya olumsuz gelişmeler, türlerin var kalmaları veya yok olmaların belirleyecektir (UN, 2019).

Günümüzde nesli tehlike altındaki türlerin tespit edilmesi, bu türlerin karşılaştıkları sorunların ortaya konmas1 ve tespit edilen faktörlerin engellenmeye çalışılmasına ilişkin pek çok çalışma sürdürülmektedir. Örneğin, memeli türlerin yok oluşlarının bağlı olduğu etkenleri ortaya çıkarmayı hedefleyen ve böylece önleyici çalışmalara 1şık tutmayı amaçlayan bir çalışma, türleri yok oluşa götüren belli başlı kriterleri ortaya koymaktadır. Buna göre türlerin biyolojik özellikleri, yaşadıkları coğrafi koşullar ve kendilerine yönlendirilen harici tehditler, türlerin yaşamaları veya yok olmalarını belirleyen faktörler olarak ortaya çıkmaktadır. Çalışmada, yakın zamanda soyları tükenecek memeli türlerin taşıdıkları özelliklerin ileri yaşta sütten kesilme, geniş yaşam alanına ihtiyaç duyma, düşük popülasyon yoğunluğunda yaşama, sınırlı coğrafi dağılım ve yaşamalanlarının büyük bölümünün insan nüfusu ile paylaşılması olarak sıralanmaktadır. Dahas1, düşük dağılım veya düşük nüfus yoğunluğuna sahip türlerin yaşam alanları, insanların yoğun olarak yerleştikleri bölgeler ise, yok oluş ihtimali katlanarak artmaktadır (örneğin Antilope cervicapra ve Hylobates moloch). Bu türlerin insansız bölgelerde yaşama şansları oldukça sınırlıdır ve bu sebeple yok oluştan kurtulmak için gerekli olan nüfus büyüklügüne ulaşamamaktadırlar (Cardillo vd., 2008, s. 1445).
Türlerin yok oluşuna ilişkin elde edilen bilgiler 1şığında koruyucu, iyileştirici veya restore edici çalışmalar gerçekleştirilmektedir. Bununla beraber, bu tür çabaların asla doğal sürecin yerini tutamayacağına ilişkin görüşler de ileri sürülmektedir. Yok olan veya yok olmak üzere olan türlerin teknoloji yardımıyla yaşatılmasının doğru olmadığını ifade eden kimi bilim insanları, milyonlarca yıllık bir süreç sonucu evrilen türlerin, dışarıdan alınan önlemlerle yaşatılmasının doğal olmadığı üzerinde durmaktadırlar. Onlara göre doğayı eski haline getirmek birçok açıdan zor veya imkânsızdır. Öncelikle doğanın kendi içinde sahip olduğu bir değer vardır ve dışarıdan, yapay yollarla bu süreci tekrar etmek, kaybolan değerin geri kazanılması anlamına gelmez. Örneğin, yok olan yağmur ormanları yerine yeni yağmur ormanlarının oluşturulması mümkündür ancak ikincisi asla doğal yağmur ormanlarının yerini tutamayacaktır. Bunun temel nedeni, ormanların biyolojik dokusunun milyonlarca yıllık bir süreçte oluşmuş olmasıdır. İkinci olarak, teknoloji yardımıyla oluşturulan doğal ortamlar veya yaşatılan türler asla doğadaki haline dönemezler çünkü sürece yapay ve dişsal bir faktör dâhildir. Sürece dâhil olan insan faktörünün varllğı, doğal sürecin kendiliğinden gelişmesini etkilemektedir. İnsan müdahalesi, ekosistemlerin veya türlerin yaşamlarının devamında bağımlılık duydukları bir faktöre dönüşmektedir. Bunun yanı sira doğal ortamların ve hassas türlerin korunması sürecinde, gerçekleşmekte olan insan eylemlerinin tahmin edilemez sonuçlar doğurabileceği de dile getirilmektedir (Elliot, 1994, s. 136-143).

Yaşanan antropojenik etmenler nedeniyle yok olan veya yok olacak olan türler ortaya konarken veya koruyucu, restore edici çalışmalar sürdürülmeye çalış1lırken, yeni türlerin neden ortaya çıkmadığı sorusu sorulabilir. Evrim teorisine göre türler, antropojenik etkenlerin ortaya koyduğu kisıtlamalara uyum sağlayarak yeni türler ortaya koymalıdır. Böylece yeni türler, yok olan türlerin yerlerini almalı ve biyoçeşitlilik zenginliğini korumalıdır. Ancak türlerin evrim geçirme yetenek ve şanslarının da antropojenik faktörler tarafindan ellerinden alındığ1 görülmektedir. Türler, biyoçeşitliliği zenginleştirecek yeni bireylere doğru evrilememekte çünkü öncelikle, tür popülasyonlarının genişleyebileceği alanlar insanlar tarafindan yok edilmektedir. İkinci olarak, yeni türler ortaya çıksa bile, biyoçeşitlilikteki kaybı telafi edemeyecek düzeyde kalmaktadır. Bunlar genellikle bitkiler, böcekler ve diğer küçük türlerdir, filler gibi büyük türleri ikame edecek türler değildir. Bunun yanında, yeni türler genellikle "ucuz" (cheap) türler olarak tanımlanırlar; dış görünüşleri atalarından çok farklı olsa da genetik olarak atalarına oldukça yakındırlar. Beslenme rejimi, yuva tercihi, bazı hastalıklara bağışı1klık gibi biyolojik özellikleri yakın akrabalarınınkine oldukça yakındır ve bu sebeple yerel bir akraba türü olarak 
biyoçeșitliliği fazlaca zenginleștiremezler. "Ucuz" türlerin de zamanla evrimleşerek genetik olarak atalarından farklı formlar alabilmeleri mümkündür. Ancak bu ihtimal, uygun yaşamalanlarının antropojenik nedenlerle kısıtlı olması nedeniyle oldukça düşük bir ihtimaldir. Kısaca biyolojik çeşitliliğe bitki ve böcek gibi türlerden yeni bireyler eklenebilse de panda gibi büyük memeli türlerin eklenmesi ihtimal dişı görünmektedir (Aitken, 1998, s. 406-407).

\section{Sonuç}

Türlerin yok oluşu, yaşam tarihi boyunca evrim ve kitlesel yok oluşlar yoluyla defalarca tekrarlanan bir olgudur. Yok oluş, çevresel koşullara daha iyi uyum sağlamak için daha ileri bir donanıma evrilme şeklinde olabileceği gibi, evrimsel donanım kazanamadan, soyun tamamen yok olması şeklinde de gerçekleşebilir. Kitlesel yok olușlar, bu ikinci türden yok oluşu ifade eder ve yaşam boyunca bilinen beş büyük yok oluş, yaşayan türlerin önemli kısmının tükenmesine neden olmuştur. Bununla beraber, yok oluşları uyanıșlar izlemiş, biyosfer felaketlerin ardından kendini iyileştirmiş ve biyoçeşitlilik yeniden oluşmuştur. Öte yandan, Homo sapiens' in ortaya çıkışı ile başlayan süreçte, biyosferde yaşanan rutin yok oluş ve uyanış döngüsünde önemli değişiklikler ortaya çıkmıștır.

Kitle yok oluşlarına neden olan doğal etkenler ile antropojenik kökenli etkenlerin birçok yönden birbirinden faklı olmaları, neden oldukları sonuçlarda da büyük farklılıklar yaratmaktadır. Büyük yok oluşların ardından kendini tekrar olușturabilen biyoçeșitlilik, antropojenik etkenlerin sürekliliği, rastlantısallığ ve içselliği gibi nedenlerle tekrar oluşamamaktadır. Bunun yanında insanların aşırı kullanımları sonucu yeterli yaşam alanı ve kaynak bulunamaması evrimsel sürecin işlemesini de engellemektedir. Böylece yok olan türler yerine tamamen yeni bireylerin geçmesi de engellenmekte, biyoçeșitlilik kaybı önlenemez hale gelmektedir.

Yerküre, karmaşık süreçler içinde birbirine bağlı ve bağımlı öğelerden oluşur. Bu karmaşık ilișkiler ağına yapılan sistematik müdahaleler, milyarlarca yılda oluşmuş olan dengeyi kalıcı biçimde tahrip etmektedir. Ekolojik dengenin bozulmasının, kısa sürede gündelik yaşamları alt üst eden sonuçlar doğurabileceğine yakından tanık olunduğu bu günlerde, biyolojik çeşitliliğin yaşamlarımız ve geleceğimizle doğrudan ilişkili olduğu anlaşılmalıdır.

\section{Kaynakça}

Aitken, G. M. (1998). Extinction. Biology and Philosophy, 13(3), 393-411. https://doi.org/10.1023/A:1006567916998

Alroy, J. (2008). Dynamics of origination and extinction in the marine fossil record. Proceedings of the National Academy of Sciences of the United States of America, 105(1), 1153611542. https://doi.org/10.1073/pnas.0802597105

Barlow, M. (2008). Mavi sǫ̈lesme: Küresel su krizi ve su hakekr Mücadelesi, B. Cezar (Çev.). Yordam Kitap. (Eserin asıl bask1s1 2007).

Brannen, P. (2017). The ends of the world: Volcanic apocalypses, lethal oceans, and our quest to understand earth's past mass extinctions. Ecco Publication.

Broswimmer, F. J. (2002). Ecocide: A short history of the mass extinction of species. Pluto Press.

Burkett, P. (2004). Marx ve doğa: Al-yeşil birperspektif, E. Özkaya (Çev.), Epos Yayınları. (Eserin asıl baskısı 1999).

Cardillo, M., Mace, G. M., Gittleman, J. L., Jones, K. E., Bielby, J. ve Purvis, A. (2008). The predictability of extinction: biological and external correlates of decline in mammals. Proceedings of the Royal Society $B$ Biological Sciences, 275(1641), 1441-1448. https://doi. org/10.1098/rspb.2008.0179

Carson, R. (1962). Silent spring. Houghton Mifflin.

Ceballos, G. ve Ehrlich, P. R. (2018). The misunderstood sixth mass extinction, Science, V. 360 (6393), 1080-1081.

https://doi.org/10.1126/science.aau0191

Château, J., Rebolledo, C., ve Dellink, R. (2011), "An Economic Projection to 2050: The OECD "ENVLinkages" Model Baseline", OECD Environment Working Papers, No. 41, OECD Publishing, Paris, https://doi. org/10.1787/5kg-0ndkjvfhf-en

Collingwood, R. G. (1999). Doğa Tasarımı, K. Dinçer (Çev.). İmge Kitabevi. (Eserin asıl bask1s1 1960).

Crutzen, P. J. ve Stoermer, E. F. (2000). The Anthropocene. IGBP Newsletter, (41), 17-18.

Des Jardins, J. R. (2006). Cevre etiği: Cevre felsefesine giris, R. Keleş (Çev.). İmge Kitapevi. (Eserin asıl baskısı 1993).

Elliot, R. (1994). Extinction, restoration, naturalness. Environmental Ethics, 16(2), 135-144. https://doi. org/10.5840/enviroethics 199416228

FAO (2021). Sustainable development goals 14.4. http://www.fao. org/sustainable-development-goals/indicators/1441/ en/ 
Foster, J. B., ve Magdoff, F. (2014). Her çevrecinin kapitalizm hakekenda bilmesi gerekenler, Ö. Aksakal (Çev.). Patika Kitap Yayınlar1. (Eserin as1l bask1s1 2011).

Foster, J. B. (2012). Marksist Ekoloji, Kalkedon Yayınları, İstanbul. (Eserin as1l bask1s1 2000).

Gaston, K. J. (2005). Progress reports biodiversity and extinction: species and people. Progress in Physical Geography, 29(2), 239-247. https://doi. org/10.1191/0309133305pp445pr

Glavin, T. (2014). The sixth extiction: Journey among the lost and left behind. St. Martin's Press.

Hallam, T. (2005). Catastrophes and lesser calamities: The causes of mass extinctions. Oxford University Press. https://doi. org/10.1093/oso/9780198524977.001.0001

Hannah, L. (2012). Saving a million species: Extinction risk from climate change. Island Press. https:// doi.org/10.5822/9781-61091-182-5

Hilborn, R., ve Hilborn, U. (2012). Overfishing: What everyone needs to know. Oxford University Press. https://doi. org/10.1093/wentk/9780199798131.001.0001

Huberman, L. (2011). Sosyalizmin alfabesi, 20. Bask1, A. Bilgi (Çev.). Sol Yayınları. (Eserin asıl baskısı 1953).

Jha, M. K. (2010). Natural and anthropogenic disasters: An overview. M. K. Jha (Ed.) içinde, Natural and anthropogenic disasters: Vulnerability, preparedness and mitigation (s. 1-16). Springer. https://doi.org/10.1007/978-90-481-2498-5

Jones, A. (2014). Impact volcanism and mass extinctions. G. Keller ve A. C. Kerr (Ed.) içinde, Volcanism, impacts, and mass extinctions: Causes and effects (s. 369381). The Geology Society of America. https://doi. org/10.1130/2014.2505(19)

Keleş, R., Hamamc1, C., ve Çoban, A. (2012). Çevre politikası, 7. Bask1. İmge Kitabevi.

Lande, R. (1987). Extinction thresholds in demographic models of territorial populations. The American Naturalist, 130(4), 624-635. https://doi.org/10.1086/284734

Leakey, R., ve Lewin, R. (1995). The sixth extinction: Patterns of life and the future of bumankind. Anchor.

Lovejoy, T., ve Hannah, L. (2019). Changing the biosphere. T. Lovejoy ve L. Hannah (Ed.) içinde, Biodiversity and Climate Change Transforming the Biosphere (s. 3-11). Yale University
Press. https://doi.org/10.2307/j.ctv8jnzw1.6

Malm, A., ve Hornborg, A. (2014). The geology of mankind? A critique of the antropocene narrative. The Anthropocene Review, 1(1), 62-69. https://doi. org/10.1177/2053019613516291

Mammadov, R. (2011). The geophytes species in the northeastern region of great caucasian (Around Azerbaijan) and effects of anthropogenic factors on their diversity and distribution. Gazi University Journal of Science, 24(1), $1-9$.

McKee, J. K., Sciulli, P. W., Fooce, C. D., ve Waite, T. A. (2003). Forecasting global biodiversity threats associated with human population growth. Biological Conservation, 115(1), 161-164. https://doi.org/10.1016/S00063207(03)00099-5

McKee, J. (2003). Sparing nature: The conflict between buman population growth and Earth's biodiversity, Rutgers University Press. https://doi.org/10.36019/9780813558776

Michalski, F. ve Peres, C. A. (2005). Anthropogenic determinants of primate and carnivore local extinctions in a fragmented forest landscape of southern Amazonia, Biological Conservation, 124(3), 383-396. https://doi. org/10.1016/j.biocon.2005.01.045

Palmer, D., ve Barrett, P. (2010). Eurim atlası, Ç. Sunay ve M. Özgüleş (Çev.). İş Bankası Kültür Yayınları. (Eserin asıl bask1s1 2009).

Pievani, T. (2014). The sixth mass extinction: Anthropocene and the human impact on biodiversity, Rendiconti Lincei, (25), 85-93. https://doi.org/10.1007/s12210-013$\underline{0258-9}$

Pimm, S. L., ve Raven, P. (2000). Biodiversity: extinction by numbers. Nature, 403(6772), 843-845. https://doi. org $/ 10.1038 / 35002708$

Polanyi, K. (2014). Büyük dönüsüm çağımıฺ̨ın siyasal ve ekonomike kökenleri, 12. Basım, A. Buğra (Çev.). İletişim Yayınları. (Eserin as1l bask1s1 1944).

Ponting, C. (2000). Dünyanm yeşil taribi: Çevre ve uygarlıklarm çöküusü, A. Başçı-Sander (Çev.). Sabanc1 Üniversitesi Yayınlar1. (Eserin as1l bask1s1 1991).

Renner, M. (2014). İklim değişikliği ve yerinden edilme, Worldwatch Enstitüsü içinde, Dünyanın Durumu 2013: Sürdürülebilirlik hâlâ mümkün mü? (s. 481-494), C. Ulutaş 
Ekiz ve Ç. Ekiz (Çev.). İş Bankası Kültür Yayınları.

Roberson, L. A., Watson, R. A., ve Klein, C. J. (2020). Over 90 endangered fish and invertebrates are caught in industrial fisheries. Nature Communications, 11(4764), 18. https://doi.org/10.1038/s41467-020-18505-6

Rockstörm, J., ve Klum, M. (2015). Big world small planet: Abundance within planetary boundaries. Yale University Press.

Schuster, S. ve Schüle, W. (2000). Anthropogenic causes, mechanisms and effects of Upper Pliocene and Quaternary extinctions of large vertebrates. Oxford Journal of Archaeology, 19(3), 223-239. https://doi. org/10.1111/1468-0092.00108

Smith, V. L. (1975). The primitive hunter culture, Pleistocene extinction, and the rise of agriculture. Journal of Political Economy, 83(4), 727-755. https://doi. org/10.1086/260353

Thomas, C. D., Cameron, A., ve Williams, S. E. (2004). Extinction risk from climate change, Nature, (427), 145148. https://doi.org/10.1038/nature02121

Travis, J. M. (2003). Climate change and habitat destruction: A deadly Anthropogenic cocktail, Proceedings of the Royal Society B Biological Sciences, 270(1514), 467-473. https:// doi.org/10.1098/rspb.2002.2246

UN (6 May1s 2019). UN report: Nature's dangerous decline 'unprecedented'; species extinction rates 'accelerating' https:// www.un.org/sustainabledevelopment/blog/2019/05/ nature-decline-unprecedented-report/

WCMC (2021). Annual review 2019: Putting nature at the heart of decision-making. https://annualreview.unep-wcmc.org/

Ünder, H. (1996). Çevre felsefesi. Doruk Yayınları.

Vitousek, P. M., Aber, J. D., Howarth, R. W., Likens, G. E., Matson, P. A., Shindler, D. W., ve Tilman, D. G. (1997). Human alternation of the global nitrogen cycle: sources and concequences. Ecological Applications, 7(3), 737-750. https://doi.org/10.1890/10510761(1997)007[0737:HAOTGN]2.0.CO;2

Wilson, E. O. (2003). The future of life. Vintage.

WWF (2021). Orangutan [İnternet sitesi]. (https://www.worldwildlife.org/species/orangutan adresinden 02.04.2021 tarihinde erişilmiştir.

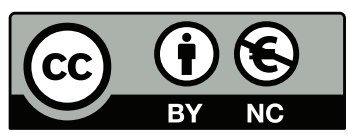

2021. Telif haklar1 yazar(lar)a aittir.

Bu makale Creative Commons Attf-GayriTicari 4.0 Uluslararası (CC BY-NC 4.0) lisansının hüküm ve şartları alında yayımlanan açık erişimli bir makaledir. 